\title{
ELECTROCHEMICAL PROPERTIES OF THE COM POSITES SYNTHESIZED FROM POLYANILINE AND MODIFIED MWCNT
}

\author{
Yaroslav Kovalyshyn¹, Myroslava Konovska ${ }^{1}$, C hiara Milanese $^{2}$, Ivan Saldan ${ }^{1,2}$, \\ Roman Serkiz ${ }^{3}$, Orest Pereviznyk ${ }^{1}$, Oleksandr Reshetnyak ${ }^{1}$, Orest Kuntyi ${ }^{4}$,
}

https:

\begin{abstract}
Electroactive composites made of polyaniline and MWCNT modified by aminobenzene groups were electrochemically synthesized. SEM observation confirms that the composites become more porous as the MWCNT aggregation on the electrode surface gradually increases. Paraboloid dependence of specific electrical conductivity on the MWCNT content was found for the composites with more than $2.0 \mathrm{wt} \%$ of MWCNT. Obtained results confirmed a strong relationship between the surface and electrical properties allowing to offer their optimization using different amount of MWCNTs and preparation procedure.
\end{abstract}

Keywords: aniline, aminobenzene, electroconductive composite.

\section{Introduction}

At the end of the last century, electro-conductive polymers (EPs) became very important materials in research and development. EPs are applied in energy sources, chemo- and bio sensors, catalytic systems, electromagnetic displays, antistatic and anticorrosion coatings, electrooptic and electrochromic devices, etc [1]. Polyaniline (PAni) was the first EP used for industrial production of energy sources and biosensors [2]. The structure of PAni is well-studied [4,5] and its chemical/electrochemical synthesis is developed to produce solid powder or thin film [3]. In a protonic state PAni shows a good ionic and electron conductivity hence

\footnotetext{
${ }^{1}$ Ivan Franko National University of Lviv,

6, Kyryla and Mefodia St., 79005 Lviv, Ukraine;

${ }^{2}$ Pavia $\mathrm{H}_{2}$ Lab, C.S.G.I. \& Department of Chemistry, Physical Chemistry Section,

University of Pavia, Viale Taramelli 16, Pavia 27100, Italy

${ }^{3}$ Center of Low-Temperature Studies, Ivan Franko National University of Lviv,

50, Dragomanova St., 79005 Lviv, Ukraine

${ }^{4}$ Lviv Polytechnic National University,

12 Bandery St., 790013 Lviv, Ukraine

*kunty@ukr.net

(C) Kovalyshyn Y., Konovska M., Milanese C., Saldan I., Serkiz R., Pereviznyk O., Reshetnyak O., Kuntyi O., 2017
}

high electrochemical capacitance [6] suggesting a promising material for effective electroactive composites (ECs). Modern nanotechnologies pay special attention to ECs based on EPs with carbon nanotubes (CNTs). Today, SWCNTs and MWCNTs are considered to be among the cheapest and most functional components for the composites. However, high dispersity and homogeneity of CNTs in the polymer matrix remain a challenge. Recently, modification of CNTs has been proposed as a possible solution to the problem [7]. In order to promote interaction between CNTs and polymer matrix, chemical grafting of aminobenzene groups to the CNTs surface was proposed and eventually found to be one of the promising approaches. Modification of the CNTs surface by aminobenzene groups has been further developed in the present work. Electrochemical synthesis of ECs based on EPs and modified CNTs has been shown in practice. Relationship between the surface and electrical properties of the prepared composites has been discussed in details.

\section{Experimental}

Cellulose, potassium chloride, sodium persulfate, sodium hypophosphite monohydrate, acetone, aniline together with hydrochloric, nitric, sulfuric and tetrafluoroboric acids were used as in [7] while MWCNTs as in [8].

\subsection{Materials and Synthesis}

4-Nitrobenzenediazonium tetrafluoroborate (NT) was synthesized according to the method proposed in [9]. Synthesis of nitrocellulose was performed in agreement with the full description in [10]. Obtained products were rinsed in distilled water, dried in air and grinded by a mortar. Solution of sodium hypophosphite $(50 \mathrm{wt} \%)$ was stirred with NT $\left(50 \mathrm{~mol} \cdot 10^{-3}\right)$ and after that MWCNTs $(0.05 \mathrm{~g})$ were added [11]. In order to obtain modified MWCNTs, the prepared mixture was stirred during $30 \mathrm{~min}$ and filtrated with distilled water and acetonitrile to remove residual sodium hypophosphite and NT. The modified MWCNTs were dried in the furnace at the pressure of $2 \mathrm{kPa}$ and constant temperature of $298 \mathrm{~K}$ for 
$\sim 20 \mathrm{~h}$. Chemical reduction of $\mathrm{NO}_{2}$ groups in the modified MWCNTs (1.23 g of each) was carried out by the solution of metallic zinc $(2 \mathrm{~g})$ in hydrochloric acid $(8.5 \mathrm{ml})$ [12]. The obtained mixture was distilled during $\sim 5 \mathrm{~h}$ and then filtered to remove residual hydrochloric acid. After the chemical treatment the modified MWCNTs were again dried under the same conditions.

\subsection{Electrochemical Synthesis of PAni Composites}

Electrochemical synthesis of PAni composites was carried out in the solution of aniline with $1.0 ; 2.0 ; 3.0 ; 5.0$; $7.5 ; 10.0$ and $20.0 \mathrm{wt} \%$ of the modified MWCNTs. Electropolymerization was done in hydrochloric acid $(1.0 \mathrm{M})$ on the surface of platinum plate $\left(S=1.0 \cdot 10^{-4} \mathrm{~m}^{2}\right)$ at constant potential of $1.00 \mathrm{~V}$ referred to silver chloride electrode (SCE). Pure PAni was electrochemically synthesized in the same way. Synthesized materials were treated in the ultrasonic bath for $3 \mathrm{~min}$ and eventually were filtered in distilled water and dried in the furnace at the pressure of $2 \mathrm{kPa}$ and constant temperature of $343 \mathrm{~K}$ during $\sim 12 \mathrm{~h}$.

\subsection{FTIR Spectroscopy and Electrochemical Properties}

Fourier transform infrared (FTIR) spectroscopy, specific electric conductivity and electrochemical capacitance of the PAni composites were measured with the instruments and according to the procedures described in [7].

\subsection{Scanning Electron M icroscopy}

Scanning electron microscopy (SEM) was performed in PEMMA-102-02 raster electron microscopy. Image collections were made from the surface of the PAni composites using a parallel electron beam with the energy of $14-20 \mathrm{kV}$. The distance between the electron source and the sample was estimated as $300 \mathrm{~mm}$.

\section{Results and Discussion}

Apparent density of the compacted (pressure of 24.5 MPa) PAni composites was calculated as the weight to the volume ratio similar as in [7]. Dependence of the density on the MWCNT content is shown in Fig. 1. Density value for pure PAni was estimated as $\sim 1.15 \mathrm{~g} / \mathrm{cm}^{3}$ that was the lowest one compared to the prepared composites. The three highest values of apparent density $\left(\sim 1.28, \sim 1.31\right.$ and $\left.\sim 1.28 \mathrm{~g} / \mathrm{cm}^{3}\right)$ were experimentally observed for PAni composites with 1.0, 2.0 and $10.0 \mathrm{wt} \%$ of MWCNT. This suggests their more dense/compact bulk structure compared to that of other PAni composites with density values of around $1.25 \mathrm{~g} / \mathrm{cm}^{3}$. That behavior might be explained by the competition between bonding of PAni macromolecules with MWCNTs and their agglomeration without any connection to the polymer. Obviously, higher MWCNT content leads to the higher number of these local agglomerations resulting in a lower contact between PAni and MWCNTs. Conclusively, the obtained results suggest that at values higher than $2.0 \mathrm{wt} \%$ of MWCNT the prepared composites start to be more porous and have a higher specific surface area.

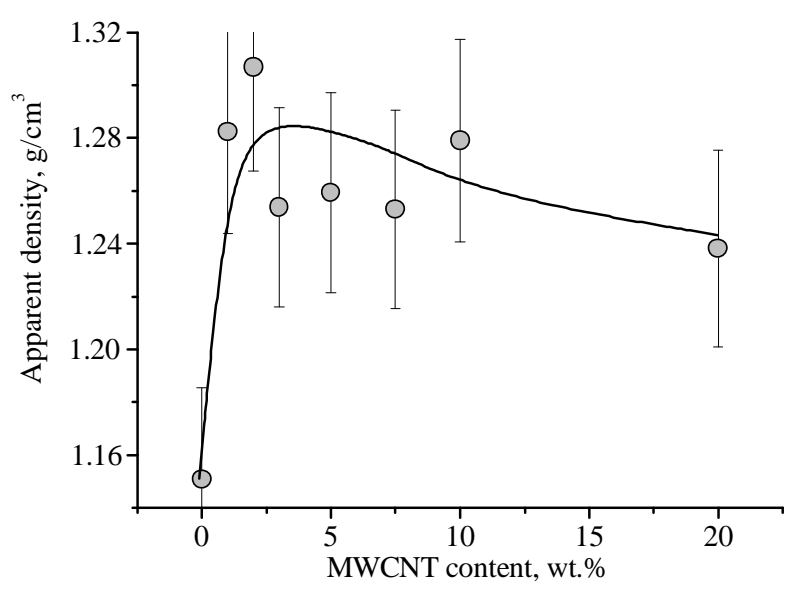

Fig. 1. Dependence of apparent density of the prepared PAni composites on their MWCNT content

The surface morphology of the electrochemically synthesized materials was analyzed by SEM at the magnification of 40 (Fig. 2). For pure PAni, SEM observation suggests a smooth layer of the polymer evenly coating a rough surface of Pt electrode (Fig. 2a). Addition of MWCNTs leads to the appearance of their aggregations and their amount increases with the increased MWCNT content (Fig. 2b-h). SEM observation is in agreement with the results of the apparent density when PAni composites become more porous since the MWCNT aggregation on the electrode surface gradually increases. The aggregation is uniformly distributed on the electrode surface, however it does not cover completely the electrode surface like polymer, therefore separate areas of smooth (PAni covered) and porous (MWCNT aggregates) surface are experimentally found by SEM. The smooth surface areas at the magnification of 10000 suggest a typical fibril structure for the polymer (Fig. 3). The fibril diameter of PAni composite with $1.0 \mathrm{wt} \%$ of CNTs is similar to that of pure PAni (Fig. 3a, b) while it becomes thicker and more compacted within the range of 2.0-10.0 wt \% of MWCNT (Fig. 3c-f). For the composite with $20.0 \mathrm{wt} \%$ of MWCNTs longer and thinner PAni fibrils were found (Fig. 3h) suggesting sterically hindered polymerization on the electrode surface because of high concentration of MWCNT aggregates. In summary, SEM observation directly confirms two types of surface morphologies that are most probably related to PAni synthesis and MWCNT aggregation at the applied electropolymerization. 

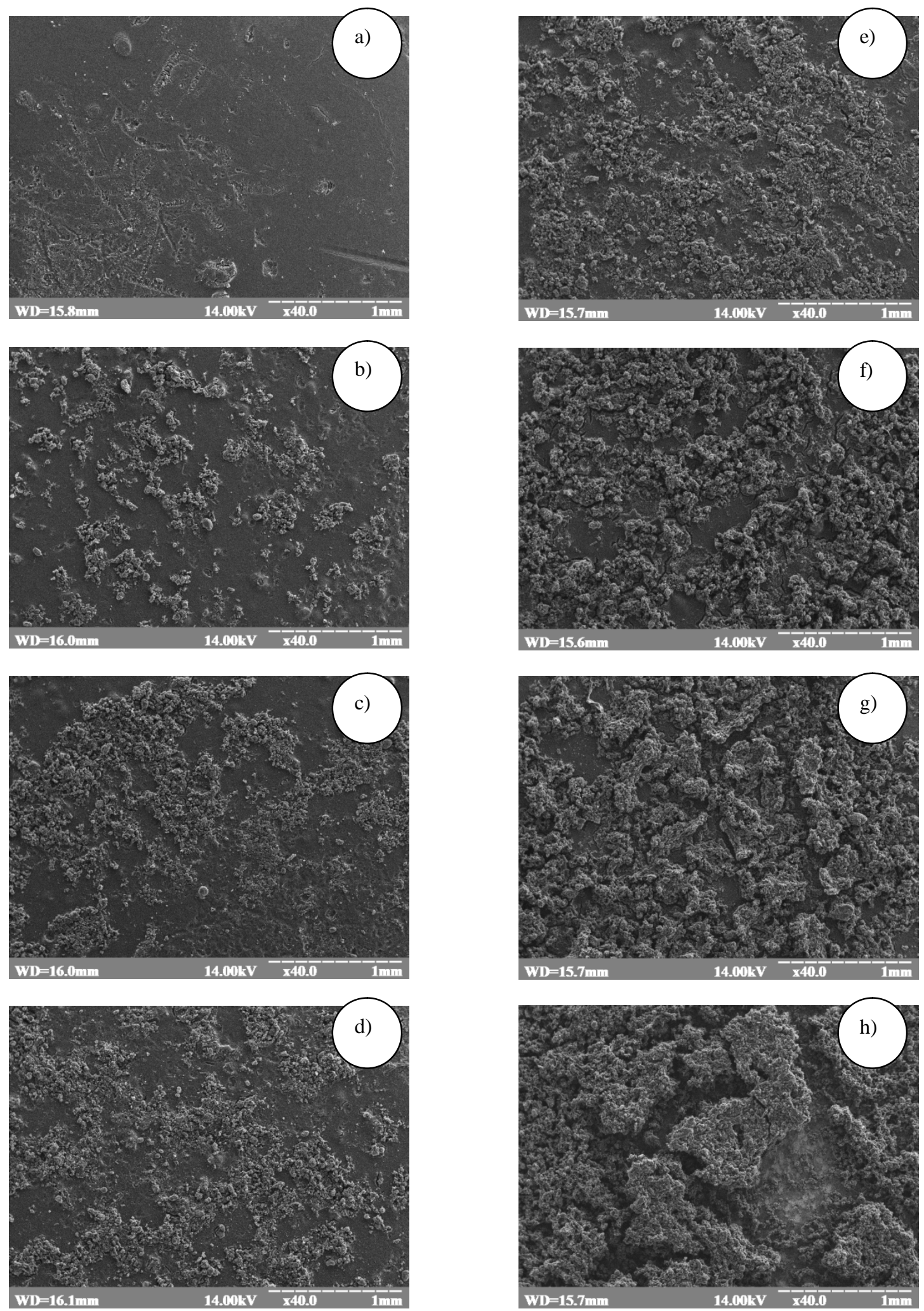

Fig. 2. SEM images for PAni (a) and PAni composites with 1.0 (b); 2.0 (c); 3.0 (d); 5.0 (e); $7.5(\mathrm{f}) ; 10.0(\mathrm{~g}) ; 20.0(\mathrm{~h})$ wt \% of the modified MWCNTs at magnification of 40 

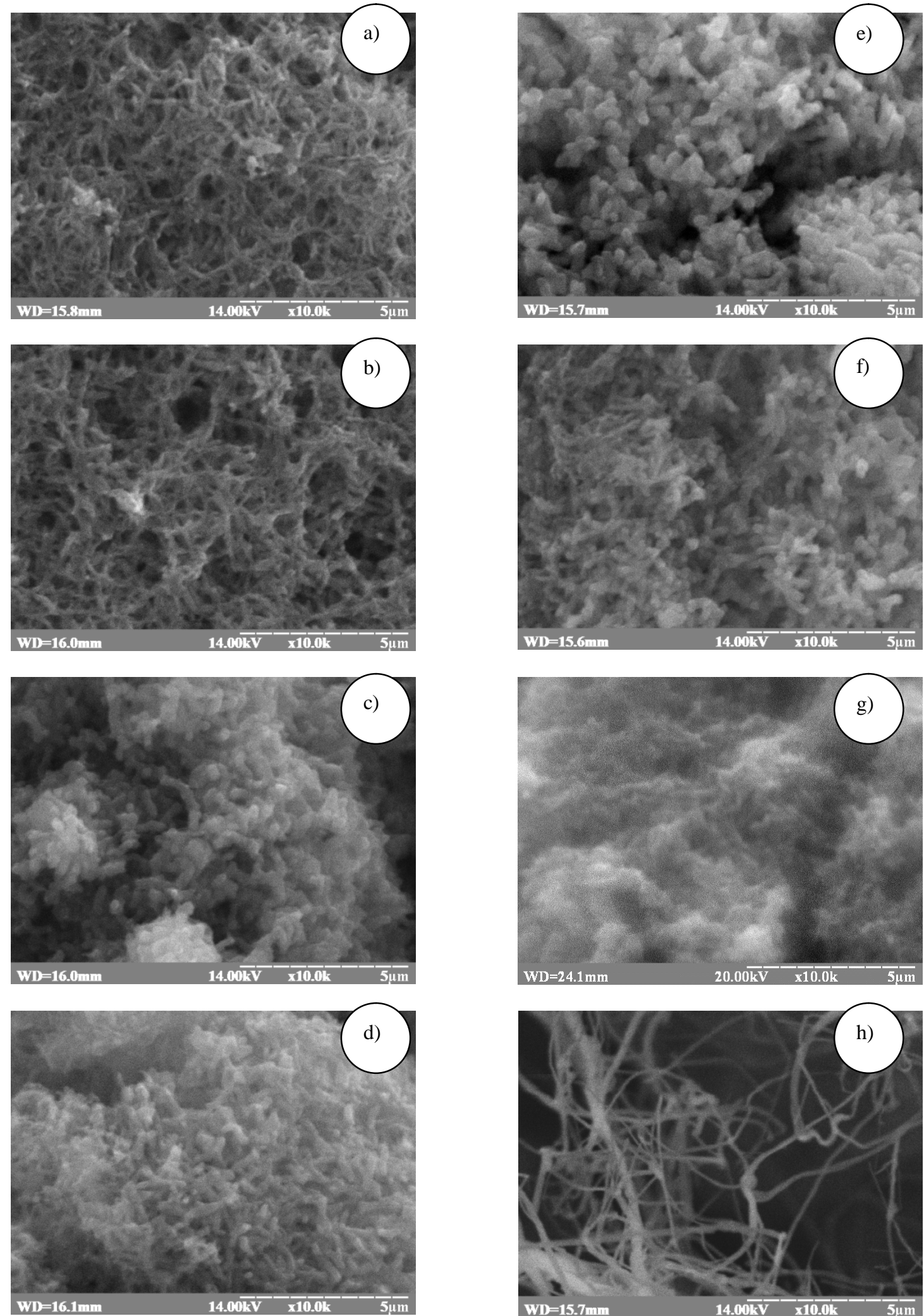

Fig. 3. SEM images for PAni (a) and PAni composites with 1.0 (b); 2.0 (c); 3.0 (d); 5.0 (e); $7.5(\mathrm{f}) ; 10.0(\mathrm{~g}) ; 20.0(\mathrm{~h}) \mathrm{wt} \%$ of the modified MWCNTs at magnification of 10000 
FTIR spectroscopy was used to analyze functional groups in pure PAni and PAni composites (Fig. 4). In the FTIR spectrum of pure PAni (Fig. 4a) some bands due to emeraldine salt are visible. First of all, the absorption bands at 1550 and $1470 \mathrm{~cm}^{-1}$ corresponded to quinoneand benzene rings in PAni chain should be noticed. These bands are not sharp since they overlap with more intense events within the range of $1455-1350 \mathrm{~cm}^{-1}$. Absorption at $1445 \mathrm{~cm}^{-1}$ might be due to $-\mathrm{C}=\mathrm{C}-$ bond in aromatic rings while that at $1380 \mathrm{~cm}^{-1}$ is due to $\mathrm{C}-\mathrm{N}$ stretching in the unit [13-15]. Absorption band at $1338 \mathrm{~cm}^{-1}$ might be assigned to $\mathrm{C}-\mathrm{N}$ vibrations in tertiary aromatic amines while that at $1276 \mathrm{~cm}^{-1}$ in the secondary ones $[13,16]$. In the region less than $900 \mathrm{~cm}^{-1}$ some absorption bands for aromatic ring were found. The signals at 900, 870, 734 and $688 \mathrm{~cm}^{-1}$ were caused by the vibration of $\mathrm{C}-\mathrm{H}$ bond in different types of substituted aromatic ring (including 1,2,4-, 1,2-, 1,4- and mono- substituted aromatic ring). A wide absorption band within the range of $2200-1630 \mathrm{~cm}^{-1}$ is a recognition of conjugated double bonds [16] (e.g. $\left.\mathrm{C}=\mathrm{C}, \mathrm{C}=\mathrm{N}, \mathrm{C}=\mathrm{N}^{+}\right)$that are typical for electroconductive form of PAni (poly radical cation of emeraldine salt) [17]. Therefore, this absorption region is highly informative to discuss the array of the conjugated bonds, hence a confirmation of charge transfer process.

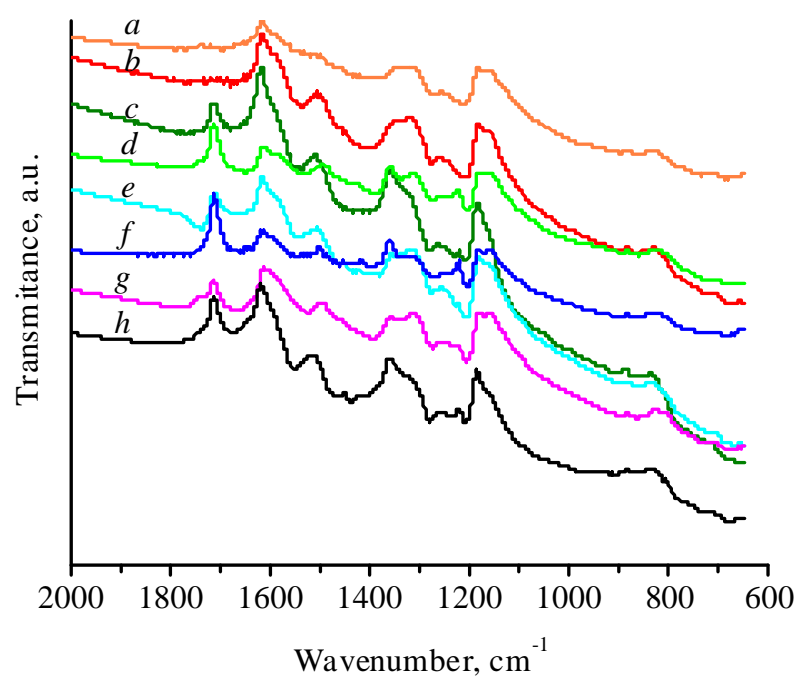

Fig. 4. FTIR for pure PAni (a) and the PAni composites with 1.0 (b); 2.0 (c); 3.0 (d); 5.0 (e); 7.5 (f); 10.0 (g); 20.0 (h) wt $\%$ of the modified MWCNTs

It is suggested that aminobenzene groups on the MWCNT surface may react with aniline in the oxidative condensation process to produce PAni grafted to the MWCNTs as it was recently proposed in [7]. The bands at 1415 and $1365 \mathrm{~cm}^{-1}$ (Fig. 4) most probably correspond to ring-stretching and $\mathrm{C}-\mathrm{N}$ bond in phenazine groups [13, 18]. Intense absorption band at $1210 \mathrm{~cm}^{-1}$ and very low ones at 910 and $855 \mathrm{~cm}^{-1}$ might be caused by the formation of phenazine groups in PAni macromolecular structure [18] (Fig. 5). Appearance of the phenazine groups correlates with low absorption intensity within the range of $1550-1470 \mathrm{~cm}^{-1}$ that are responsible for quinoneand benzene rings in a polyaniline chain; at $1235 \mathrm{~cm}^{-1}$ caused by $\mathrm{C}-\mathrm{N}^{\circ+}$ vibrations in a polaron structure of PAni; and at $1338 \mathrm{~cm}^{-1}$ that corresponds to $\mathrm{C}-\mathrm{N}$ vibration in tertiary aromatic amines. The increase of MWCNT concentration results in some changes in the FTIR spectra (Fig. 4b-h). Beginning from $1.0 \mathrm{wt} \%$ of MWCNT a sharp separation and increase of intensity of absorption bands at 1550 and $1470 \mathrm{~cm}^{-1}$ are observed. Appearance of absorption band at $1235 \mathrm{~cm}^{-1}$ started in PAni composites with MWCNT concentration of $2.0 \mathrm{wt} \%$. Additionally, the absorption band at $1680 \mathrm{~cm}^{-1}$ is singled out that might be explained by two mutually opposite events: 1) appearance of $\mathrm{C}=\mathrm{N}^{+}$- groups of phenazine, or 2) quinoneand benzene rings and $\mathrm{C}-\mathrm{N}^{\circ+}$ groups in a polaron structure of PAni. It is suggested that formation of the charged $\mathrm{C}=\mathrm{N}^{+}-$groups of phenazine is not so much evident as $\mathrm{C}-\mathrm{N}^{\bullet+}$ groups in polaron structure of PAni. However, when a large amount of the radical cations is formed during the electrochemical oxidation of aniline on the electrode surface, promotion of joining links at polymer chain growth in para- and in more sterically hindered ortho-positions might be possible. As it has been mentioned before, addition of MWCNTs leads to the increase in the surface area, hence lower concentration of the radical cations might be prepared under the same conditions of electropolymerization. Therefore, preference of the joining links in para-positions takes place increasing the selectivity of their connection. Observed changes in the FTIR spectra suggest that addition of MWCNTs influences PAni electropolymerization.

Specific electrical conductivity was calculated for pure PAni and PAni composites. A paraboloid dependence of specific electrical conductivity on the MWCNT content is found for the prepared composites (Fig. 6). Gradual increase of the specific electrical conductivity at values higher than $2.0 \mathrm{wt} \%$ of MWCNT could be explained by the fact that MWCNTs are the component with a relatively higher conductivity. The percolation threshold (before $2 \mathrm{wt} \%$ of the MWCNTs) is similar while the values of specific electric conductivity are lower as compared to those of the chemically synthesized PAni composites in [7] suggesting a lower interaction between PAni and MWCNT. During PAni synthesis in aniline and aminobenzene groups of the modified MWCNT under appropriate electron flow or chemical oxidizer [7], radical cations might be formed and then through their association connection between PAni and MWCNT are provided. It is suggested that during electrochemical synthesis probability of the radical cations formation is not as high as in the chemical method [7] since the electrochemical process takes places only on the electrode surface that means that there is a space limita- 
tion for MWCNTs as compared to that of the bulk of chemical reactor in [7]. It means that modified MWCNTs chemically grafted to the PAni on the electrode surface might eventually block the further ordered bonding between PAni and MWCNT and as a result the aggregations of MWCNT appear on the top. Therefore, using electrochemical synthesis lower ordering of the modified
MWCNT connected to PAni is more probable compared with those in the chemical approach proposed in [7] which, in turn, leads to a bit lower specific electrical conductivity. It should be noticed that values of specific electrical conductivity for the chemically synthesized PAni composites prepared with unmodified MWCNT [7] are much lower as compared to the results obtained in Fig. 6.<smiles>CC(C)(C)Nc1ccc(Nc2ccc(Nc3ccc(Nc4ccc(Cl)cc4)cc3)c(Nc3ccc(Nc4ccc(C(F)(F)F)cc4)cc3)c2)cc1</smiles><smiles>CC(C)c1ccc(Nc2ccc3nc4cc(Nc5ccc(C(C)(C)C)cc5)ccc4[n+](-c4ccc(NC(C)(C)C)cc4)c3c2)cc1</smiles>

a)<smiles>CNc1ccc(Nc2ccccc2Nc2ccccc2)cc1</smiles><smiles>CNc1ccc(N2c3ccccc3Nc3ccccc32)cc1</smiles><smiles></smiles><smiles>Nc1ccc(Nc2ccccc2Nc2ccccc2)cc1</smiles><smiles></smiles>

b)

Fig. 5. Scheme for the formation of branched (a) and substituted (b) phenazine-like elements from polyaniline chains with 1,2,4-trisubstituted and 1,4-disubstituted aromatic rings, respectively [18]

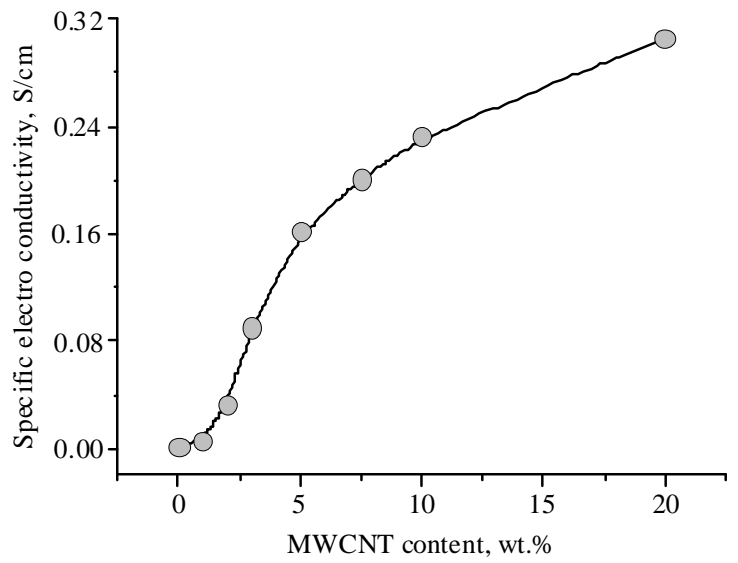

Fig. 6. Dependence of specific electrical conductivity of the prepared PAni composites on their MWCNT content 

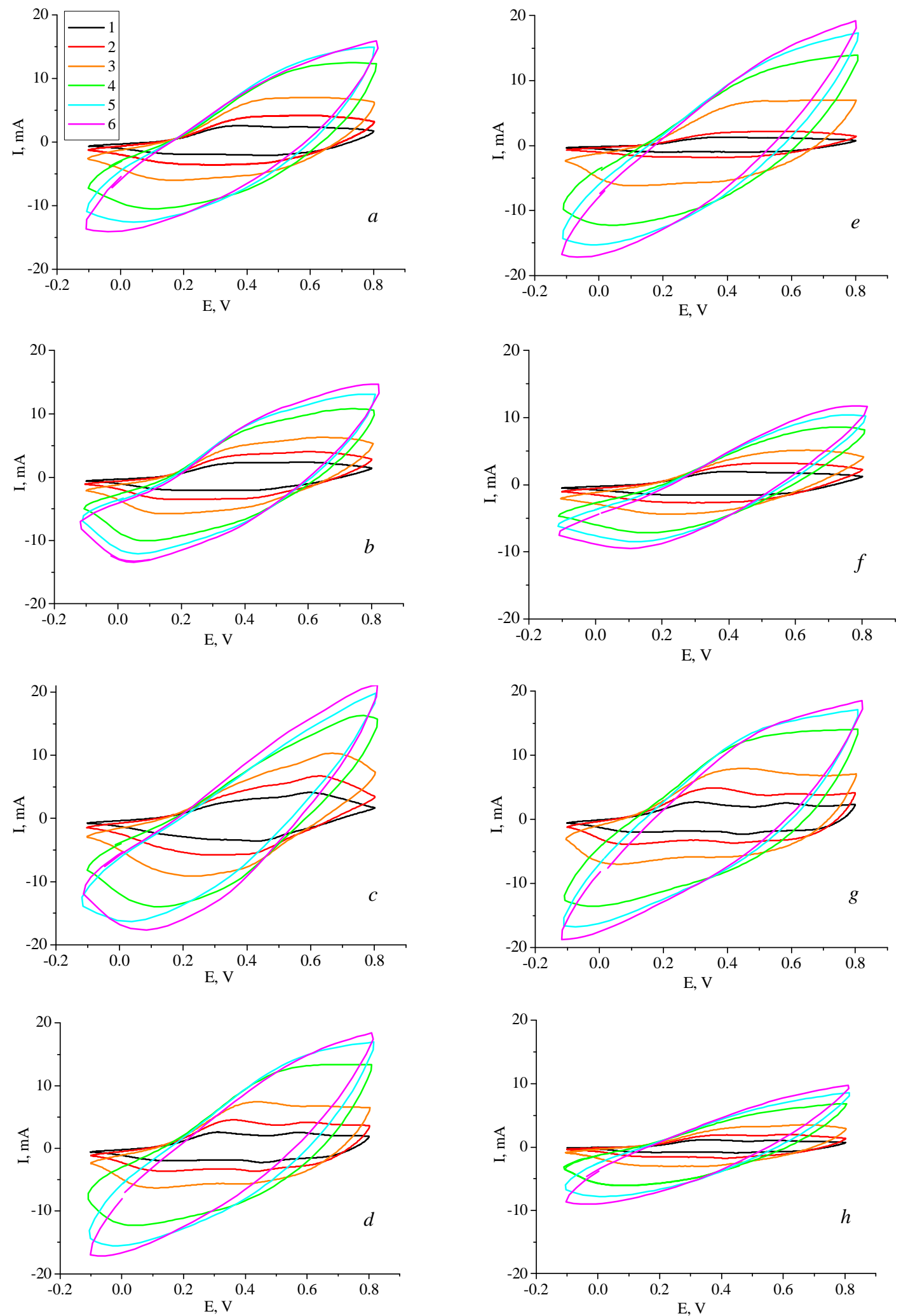

Fig. 7. CV diagrams for pure PAni (a) and the PAni composites with 1.0 (b); 2.0 (c); 3.0 (d); 5.0 (e); 7.5 (f); 10.0 (g); 20.0 (h) wt \% of the modified MWCNTs at the scanning rate of $5(1) ; 10(2) ; 20(3) ; 50(4) ; 75(5)$ and $100(6) \mathrm{mV} / \mathrm{s}$ 
For the PAni composites, cyclic voltammetry (CV) at various scanning rates was measured (Fig. 7). The current values became elevated during gradual increase of the scanning rate that confirms limitation of the electrochemical process by the diffusion of the active species to the electrode surface. The values of current maximum of redox processes in pure PAni are very low suggesting a strong contribution of the charged double electric layer to the values of the measured current. Experimental current values of the prepared composites depend on the MWCNT content hence on specific surface area and correlate with apparent density and electrical conductivity. Dependences of the current of $\mathrm{CV}$ diagrams at $0.600 \mathrm{~V}$ on the square root of the potential sweep rate for all prepared PAni composites are shown in Fig. 8.It is known that for planar diffusion-controlled electrochemical process the peak of current $\left(I_{\mathrm{p}}\right)$ is calculated by RandlesSevcik equation:

$$
I_{\mathrm{p}}=k^{2 / 3} A D^{1 / 2} C v^{1 / 2}
$$

where $k, A, D, C$ and $v$ are the Randles-Sevcik constant, electrode surface area, diffusion coefficient, volume concentration of the active material and potential sweep rate, respectively.

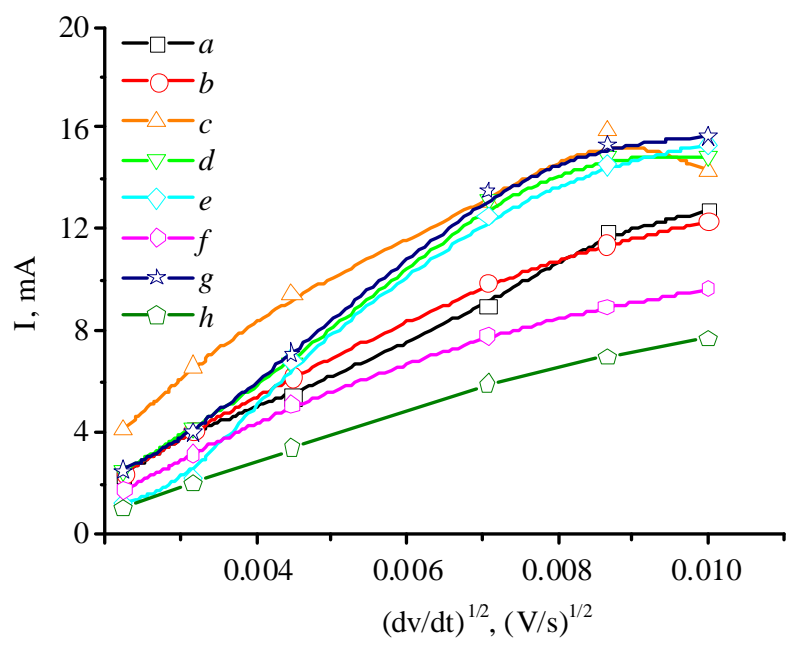

Fig. 8. Dependences of the current measured from $\mathrm{CV}$ diagrams at $0.600 \mathrm{~V}$ on the square root of the potential sweep rate for pure PAni (a) and the PAni composites with 1.0 (b); 2.0 (c); 3.0 (d); 5.0 (e); 7.5 (f); 10.0 (g); 20.0 (h) wt \% of the modified MWCNTs

According to the equation, the current value is proportional to the square root of the potential sweep rate that is found practically for all prepared composites and pure PAni. This fact suggests that diffusion is the ratelimiting step for the electrochemical process. However, at the higher values of the potential sweep rate the current values start to be stabilized suggesting that concentration of $\mathrm{Cl}^{-}$ions close to the electrode surface is not enough to form a completely double electric layer and PAni doping during its oxidation. This deviation from the linear relationship in Fig. 8 might be caused by the fact that diffusion flux will be unable to provide an approach to the surface of the required amount of PAni to be involved in the electrochemical process. Based on the previous results, it was expected that the highest current values might be within the range of $2.0-10.0 \mathrm{wt} \%$ MWCNT content in the PAni composites.

\section{Conclusions}

The MWCNTs modified by aminobenzene groups were used for electrochemical synthesis of PAni composites. SEM observation confirms that PAni composites become more porous since the MWCNT aggregation on the electrode surface gradually increases. Paraboloid dependence of specific electrical conductivity on the MWCNT content was found for the PAni composites with more than $2.0 \mathrm{wt} \%$ of MWCNT. It is suggested that higher electrical properties might be in the composites with more ordered bonding between PAni and MWCNT.

\section{Acknowledgments}

The research work was financially supported by Cariplo 2013-0592 project obtained by Italian Cariplo Foundation and HF-149F project of the Ministry of Education and Science of Ukraine.

\section{References}

[1] Volkov S., Kovalchuk E., Ohenko V., Reshentnyak O.: Nanokhimiya. Nanosystemy. Nanomaterialy. Naukova dumka, Kyiv 2008.

[2] Eftekhari A.: Nanostructured Conductive Polymers. Wiley, Weinheim 2010. https://doi.org/10.1002/9780470661338

[3] Chiang J., MacDiarmid A.: Syn. Met., 1986, 13, 193. https://doi.org/10.1016/0379-6779(86)90070-6

[4] Feast W., Tsibouklis J., Pouwer K. et al.: Polymer, 1996, 37, 5017. https://doi.org/10.1016/0032-3861(96)00439-9

[5] Abalyayeva V., Bogatyrenko V., Anoshkin A. et al.: Macromol. Comp., 2010, 52, 724

[6] Kinlen P., Liu J., Ding Y. et al.: Macromolecules, 1998, 31, 1735. https://doi.org/10.1021/ma9714301

[7] Kovalyshyn Y., Gudz Y., Reshetnyak O. et al.: Proceed. Int. Symp. on Functional Materials and Nanotechnologies, Lithuania, Vilnius 2015, 152.

[8] Sementsov Yu., Melezhyk A., Prykhodko D. et al.: Fizika i Khimiya Nanomaterialov i Macromolecularnye Struktury. Naukova dumka, Kyiv 2007.

[9] Maas G., Tanaka M., Sakakura T.: E-eros Encyclopedia of Reagents for Organic Synthesis. Wiley, Chichester 2001.

[10] Dombrovski A., Naydan V.: Organichna Khimiya. Vyd-vo Lviv Nat. Univ., Lviv 1992. 
[11] Kovalchuk E., Tomilov A., Krupak A. et al.: Rus. J. Electrochem., 2011, 47, 1125. https://doi.org/10.1134/S1023193511100077 [12] Kovalchuk, E., Krupak A., Ohenko V.: Nanostruct. Mater. Sci., 2009, 2, 69.

[13] Vasylchenko O.: PhD thesis, Kharkiv Polytechnic University, Kharkiv 1995.

[14] Pokhodenko V., Krylov V.: Theor. Exp. Chem., 1994, 3, 111. https://doi.org/10.1007/BF00538188

[15] Cai L., Zhou S.: J. Electroanal. Chem., 1997, 421, 45. https://doi.org/10.1016/S0022-0728(96)04836-X

[16] Yatsyshyn M., Kovalchuk E.: Praci Nauk. Tovar. im. Shevchenka, 2008, 21, 87.

[17] Iijima S.: Nature, 1991, 354, 56. https://doi.org/ 10.1038/354056a0

[18] Trchova M., Sedenkova I., Konyushenko E. et al.: J. Phys. Chem. B, 2006, 110, 9461. https://doi.org/10.1021/jp057528g

Received: September 29, 2016 / Revised: October 25, 2016 /

Accepted: J anuary 20, 2017

\section{ЕЛЕКТРОХІМІЧНІ ВЛАСТИВОСТІ КОМПОЗИТІВ, СИНТЕЗОВАНИХ 3 ПОЛІАНІЛІНУ I МОДИФІКОВАНИХ БАГАТОСТІНКОВИХ КАРБОНОВИХ НАНОТРУБОК}

Анотація. Електрохімічним способом синтезовано електроактивні композити, приготовлені з поліаніліну $i$ багатостінкових карбонових нанотрубок (БСКНТ), модифікованих амінобензольними групами. За допомогою растрової електронної мікроскопї підтверджено, що композиційні матеріали стають більш пористими, оскільки агрегачія БСКНТ на поверхні електрода поступово збільшується. Для композитів з масовим вмістом БСКНТ більше 2,0 \% знайдено параболоїдну залежність питомої електропровідності від вмісту БСКНТ. Отримані результати підтвердили тісний взаємозв'язок між поверхнею і електричними властивостями, щзо дає змогу запропонувати їх оптимізацію, використовуючи різну кількість БСКНТ і метод приготування.

Ключові слова: анілін, амінобензол, електропровідний композит. 